\title{
GRAEBER, David. Bullshit jobs: a theory. New York: Simon \& Schuster, 2018. 333 p.
}

\author{
Guillermo Stefano Rosa Gómez \\ *Universidade Federal do Rio Grande do Sul - Porto Alegre, RS, Brasil \\ Doutorando em Antropologia Social (bolsista Capes) \\ guillermorosagomez@gmail.com \\ https://orcid.org/0000-0003-2902-9993
}


O avanço tecnológico, em vez de libertar as pessoas das longas e repetitivas jornadas de trabalho, fez com que elas trabalhassem mais e em coisas que não querem ou não gostam. Bullshit jobs, livro do antropólogo norte-americano David Graeber, trata do crescimento dos "empregos sem sentido" ou, mais especificamente, dos bullshit jobs, termo que não é necessariamente sinônimo de má remuneração ou de condições precárias de trabalho. São nomeadas assim as formas de emprego desnecessárias ou perniciosas, das quais nem mesmo o empregado consegue justificar a existência, ainda que, como parte das exigências empregatícias, se sinta obrigado a parecer que esse não é o caso. Parte do fenômeno também inclui os processos de "bullshitization", isto é, de crescimento na quantidade de tarefas sem sentido nos empregos com reconhecido valor social.

Mas quem define o que é um emprego necessário? O autor deixa isso a cargo da interpretação dos próprios trabalhadores, afirmando que não há ninguém melhor do que eles para medir o valor social de seus empregos. Segundo essas prerrogativas, o estudo de Graeber se estruturou metodologicamente a partir das repercussões que seu primeiro ensaio sobre o assunto teve em jornais e blogs, desde sua publicação em 2013. Em um segundo momento, criou um e-mail para que pessoas que se consideravam em um bullshit job escrevessem contando sobre a experiência. A partir dos mais de 250 testemunhos que recebeu após ter divulgado a proposta em diversas redes sociais, buscou esmiuçar a categoria, criando tipologias que ajudaram a dar condição objetiva ao fenômeno.

O autor propõe um enfoque analítico na condição subjetiva - os "efeitos morais e psicológicos" - dos bullshit jobs. Não foram incomuns relatos de pessoas que recebem remuneração bastante alta, tenham como função apenas atender uma ligação telefônica por dia e se sintam extremamente infelizes com isso. Por que isso acontece? Por que esse não é o emprego dos sonhos? Afinal, menor esforço e maior lucro seria o ideal para um homo oeconomicus, sujeito da escolha racional. A fim de evidenciar a predominância dos sentimentos de depressão e inutilidade em casos como esses, Graeber retoma o estatuto moderno do tempo e do trabalho.

A constituição ocidental moderna do tempo de trabalho o transformou em mercadoria e instaurou a separação epistemológica entre a pessoa e sua força de trabalho. Nessas condições, se o trabalhador está ocupando seu tempo 
- mesmo que o tenha "de sobra" - fazendo qualquer outra coisa que não aquilo determinado pelo patrão, ele está roubando. A condenação moderna do ócio faz com que ter um bullshit job inclua situações de sofrimento social, pois se faz necessário um trabalho emocional no intuito de "fingir que está trabalhando", atitude necessária para manter a ficção de que se desempenha algo útil mesmo sabendo e sentindo que não. Apesar disso, algumas pessoas conseguem se insubordinar a essas condições, buscando um senso de propósito mobilizado por "tecnologias mentais para fazer o trabalho suportável".

Mas como a existência de trabalhadores pagos para não trabalhar chegou a ser uma realidade? Por que esse tipo de emprego está proliferando? Uma interpretação mais imediata apontaria que essa é uma característica dos empregos públicos, criados somente para manter as pessoas com vínculos sociais. Graeber não desconsidera que existem bullshit jobs no setor público, mas direciona sua crítica ao crescimento do setor F.I.R.E. (finanças, seguros e imobiliário) como o que mais acumula esse tipo de emprego.

Com a finalidade de conseguir evidenciar a existência de bullshit jobs no setor privado, o antropólogo se contrapôs às diferentes explicações que os "entusiastas do mercado" davam para a existência de empregos sem sentido. Alguns dos principais argumentos são de que o trabalho deve ser útil por algum motivo que os trabalhadores não entendem ou, ainda, a existência dos empregos inúteis de "papelada" no setor privado seria causada pela intromissão estatal.

A difícil aceitação por parte dos que argumentam a favor de uma regulação livre do mercado é justamente a tensão provocada pela mera existência dos bullshit jobs: eles desafiam a lógica conceitual do capitalismo, baseada na ideia de pagar ao menor número de trabalhadores o menor valor possível e buscar o maior lucro. Criticando esse conceito de capitalismo, Graeber mostra que a aparição dos bullshit jobs faz mais sentido se considerarmos uma lógica feudalista, na qual a economia e a política se sobrepõem. Instituições too-big-to-fail seriam exemplos contemporâneos.

Se existem diversos empregos que não deveriam existir, por que não nos opomos a isso enquanto sociedade? Para responder, o autor convida os leitores a refletir sobre o que significa o trabalho no Ocidente e como tem sido medido seu valor social. Partindo da distinção - não dicotômica e com vários "vazamentos" entre valor (econômico, quantificável) e valores (belo, verdade, o amor, categorias 
imensuráveis), questiona o quanto profissões que têm uma contribuição social alta (lixeiros, professores de escolas primárias, etc.) são as menos remuneradas economicamente, com raras exceções. Essa desproporcionalidade, para Graeber, está ligada ao ethos moderno de sacrifício para um bem comum, que leva ao consenso de que trabalhar não é algo bom, mas não trabalhar é ainda pior.

O livro busca narrar o trajeto antropológico do trabalho na sociedade ocidental, evidenciando sua raiz teológica. O conceito "trabalho" é comumente associado a algo oposto ao divertimento, uma atividade onerosa e repetitiva, um meio para atingir algo. Os mitos fundadores de Adão e Prometeu, ambos punidos com o trabalho, acompanham o molde dessa definição. Nessa concepção, o trabalho tem caráter duplo de punição e criação, e o conceito de "produção" deriva das ações de um Deus judaico-cristão que cria o universo a partir do nada, atuando como um artífice. Outro eixo desse trajeto se assenta sobre a noção de "serviço", derivada da Idade Média. Naquele contexto, se tornar adulto perpassava um processo no qual o aprendiz deveria "servir", mediante atividade remunerada. Com essas influências, se funda o conceito moderno de trabalho, no qual ele é visto como virtude em si mesmo e meio de formação do caráter. Também se estabelece o "paradoxo do trabalho moderno": as pessoas obtêm dignidade trabalhando e, ainda assim, uma menor parte realmente gosta do que faz. Trabalho é, simultaneamente, nobre e doloroso.

Expostas as raízes antropológicas que dão substrato para compreensão dos bullshit jobs, cabe interrogar quais seus impactos políticos. Graeber reconhece que ao apontar em seu livro que essa forma de emprego é um problema da sociedade enquanto todo, coloca a necessidade de propor uma solução. Apesar de indicar que sua obra é mais diagnóstica do que propositiva, seleciona dentre as alternativas políticas já existentes uma que ajudaria a minimizar a existência dos bullshit jobs. A política selecionada são programas de basic income, uma renda mínima distribuída a toda população, que permitiria desassociar o trabalho dos meios de subsistência, prevenindo a compulsão por trabalhar e possibilitando que as pessoas escolham preencher seu tempo com atividades que sentem ser úteis ou benéficas aos outros e a si mesmos. Esse novo modelo oportunizaria eliminar inclusive o sadismo nas relações hierárquicas de trabalho, afinal se a vida dos sujeitos não dependesse de seu emprego poderiam dizer "eu me demito" mais facilmente ou, em última instância, teriam tempo para se organizarem politicamente. 
Por fim, a obra de David Graeber dá voz aos sujeitos trabalhadores, desde uma diversidade de contextos e profissões. O livro se soma a outros estudos de fôlego do autor, como Dívida (Graeber, 2016), nas quais a antropologia histórica tem papel preponderante em interpretar os dilemas contemporâneos. Também se insere em seu trajeto intelectual de reflexões sobre uma teoria do valor social (Graeber, 2013). A leitura interessará pesquisadores e pesquisadoras atentos(as) às transformações no trabalho, conceito fundamental em nossa constituição enquanto sujeitos modernos.

\section{Referências}

GRAEBER, D. It its value that brings universes into being. HAU: Journal of Ethnographic Theory, v. 3, n. 2, p. 219-243, 2013.

GRAEBER, D. Dívida: os primeiros 5000 anos. São Paulo: Três Estrelas, 2016. 